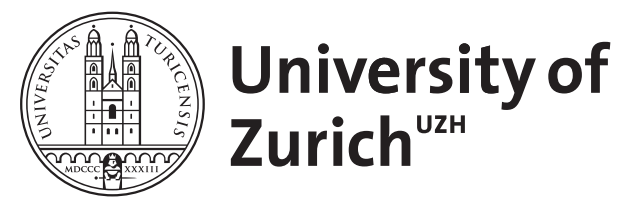

\title{
Law for what ails the heart: Moral frailty in Psalm 86
}

\author{
Lasater, Phillip Michael
}

\begin{abstract}
Psalm 86 is a text that displays intertextual engagement with Exodus $32-34$ and Jeremiah 30-33, both of which are older than the psalm. In studies of Psalm 86, a neglected issue is its anthropology, particularly the notion of the »divided heart«, which, according to the psalmist, is an ethical and theological problem that can only be solved by receiving instruction from Yhwh - an instruction that can »unify « the divided heart. By paying attention to the psalmist's application and reworking of older texts, as well as to the Rabbinic reception of Psalm 86, one can see how this text is part of an exilic and post-exilic conversation about human sinfulness as a flaw in human nature that impairs moral agency.
\end{abstract}

DOI: https://doi.org/10.1515/zaw-2015-0036

Posted at the Zurich Open Repository and Archive, University of Zurich ZORA URL: https://doi.org/10.5167/uzh-123834

Journal Article

Published Version

Originally published at:

Lasater, Phillip Michael (2015). Law for what ails the heart: Moral frailty in Psalm 86. Zeitschrift für die alttestamentliche Wissenschaft, 127(4):652-668.

DOI: https://doi.org/10.1515/zaw-2015-0036 


\section{Phillip Michael Lasater* \\ Law for what ails the heart: Moral frailty in Psalm 86}

DOI 10.1515/zaw-2015-0036

Judging from the intertextual activity between Psalm 86 and the earlier text blocks of Exodus 32-34 and Jeremiah 30-33, this psalm likely originated in the exilic or post-exilic period. An overlooked issue in the petition of Ps 86,11 is the notion of the »divided « heart, which, according to the psalmist, is an ethical and theological problem that can only be solved by receiving instruction from Yhwh - an endowed, »unifying « instruction inseparable from divine חסד. By attending to the psalmist's reapplication and reworking of other texts, as well as to the Rabbinic reception of Psalm 86, one can see how this text is part of an exilic and post-exilic discussion of human sinfulness as a problem that is internal to human beings and that impairs moral agency.

\section{The text of Psalm 86}

\footnotetext{
${ }^{1 .}$ A prayer of David

Incline your ear to me, O Yhwh, answer me; for I am poor and needy.

2. Preserve my נפש, for I am loyal; O you, my God, deliver your servant who trusts in you.

3. Be gracious to me, O Adonai, for to you I cry all day long.

4. Gladden the נפש of your servant, for to you, O Adonai, I lift up my נפש.

5. For you, O Adonai, are good and forgiving, great in steadfast love for all who call to you.

6. Hear my prayer, O Yhwh; listen to the sound of my pleading.

${ }^{7}$. In my day of affliction, I call you, for you answer me.

8. There is none like you among the gods, O Adonai, nor are there any works like yours.

9. All the nations that you made will come and bow down before you, O Adonai; they will glorify your name.

10. For you are great and a worker of wonders; you alone are God.
}

*Kontakt: Phillip Michael Lasater, Universität Zürich, phillip.lasater@uzh.ch 


\footnotetext{
ירא 11. Teach me your way, O Yhwh, that I may walk in your truth; unify my לבב that it may your name; ${ }^{2}$

12. I will praise you, ${ }^{3} \mathrm{O}$ Adonai my God, with my whole לבב; I will glorify your name always.

13. For your steadfast love toward me is great and you have delivered my נפש from the depth of Sheol.
}

14. $\mathrm{O}$ God, insolent men have risen up against me and a band of ruthless men have sought my נפש

15. But you, O Adonai, are a God compassionate and gracious, patient and great in steadfast love and truth. ${ }^{5}$

16. Turn to me and be gracious to me, give your strength to your servant and deliver the son of your maidservant.

${ }^{17}$ Show me a sign of favor, that those who hate me might see and be ashamed; for you, O Yhwh, have helped me and comforted me.

1 Although somewhat unique, the meaning of Piel יחי is not difficult to understand. Altering

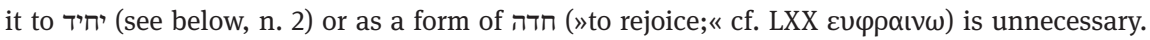
The intertextual relationship between Ps 86,11 and Jeremiah 32 further reduces the validity of repointing יחי. For more discussion, see the appendix in this paper.

2 The bicola of v. 11 begin with imperatives (Hif. יחד and Pi) that precede other verb forms.

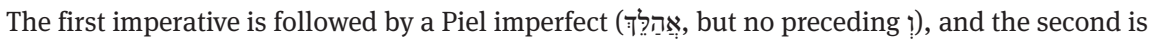

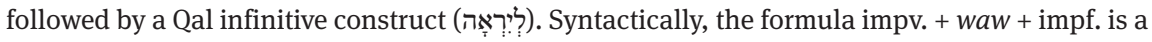
way that Hebrew can express purpose (i.e., »Do $x$, in order that $y$ might be the case. «). Likewise, the infinitive construct with ? can express purpose. The sense in v. 11 is, ״... unify my heart that it may ירא your name" (cf. Jer 32,39, with לרך אחד ,לב אחד, and ליראתי אותי). Indeed, in view of

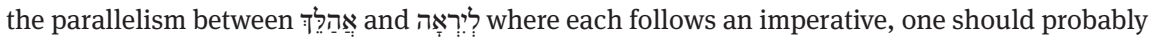
read each as expressing purpose, despite the lack of a waw with Furthermore, the verbs expressing purpose seem contingent on the fulfillment of the volitional forms (i.e., Hif. ירה and Pi. יחד). One finds the same combination of impv. + impf. in v. 17. On final clauses and the blurry line between expressions of purpose and result in ancient Hebrew, see Paul Joüon and Takamitsu Muraoka, A Grammar of Biblical Hebrew, Part Three: Syntax (Rome: Editrice Pontificio Istituto Biblico, 2005), 384-386; 633-635. On this translation of without the conjunction, see Mitchell Dahood, Psalms II, 51-100, AB 17 (New York: Doubleday, repr. 1970), 295 n. 11. He points to the Ugaritic statement, $r d$ lmlk amlk (UT 127,37 f.: »Come down from your royal seat that I may reign«). However, Dahood’s repointing of יִיחיד (»alone, only«), which he takes to modify באמתך, is speculative and unnecessary. More generally on the form waw + impf. or weyiqțol as expressing purpose or result, see Joel Baden, »The wayiqtol and the Volitive Sequence, «Vetus Testamentum 58 (2008): 147-158.

3 In 86,12, one could also translate אוֹ אוֹ as subsequent to - and therefore as contingent upon - Yhwh's »unifying « the psalmist's heart. ליראה governs both the infinitive construct (purpose statement \#1) and the yiqțōl אודך (purpose statement \#2).

4 Cf. the »divided « heart from v. 11. 86,12 presents the hoped for »unified« or »whole« heart. 5 Cf. the formulaic language in Ex 34,6; Num 14,18; Joel 2,13; Jon 4,2; Ps 103,8; 145,8; Neh 9,17. 


\section{Literary context, form, and intertextual links}

\subsection{Context within the Psalter and literary form}

In the broader context of the Psalter, Psalm 86 is in Book 3 (Psalms 73-89), the midpoint of the overall collection. Within Book 3 specifically, one finds the psalms of Asaph (Psalms 73-83) followed by a group of six "mixed « psalms: four from the Korahites (Psalms 84-85 + 87-88), one from David (Psalm 86), and one from Ethan (Psalm 89), amounting to a total of seventeen psalms. Although the reason for this placement of a Davidic psalm between four Korahite psalms is not wholly evident, the coupling of these six »mixed « psalms with the preceding eleven Asaphite psalms may have something to do with editorial concerns in the finalizing of Book 3, which consists of seventeen psalms. Casper J. Labuschagne ${ }^{6}$ has recently argued that the editors of the Psalter deliberately used the numbers $7,11,17$, and 26 as structuring devices - the latter two of which correspond to the numerical values of the divine name יהוה. According to this somewhat mechanical picture of scribal editing, ${ }^{7}$ the Davidic title of Psalm 86 is subordinated to a redactionally late, numerically-driven structural design, which may coincide with the time when the psalm was placed into the psalter. But indeed, without any reference to this number-based schema, Frank-Lothar Hossfeld and Erich Zenger assign Psalm 86 to the final redaction of the Psalter, where it is now integrated. ${ }^{8}$ In its setting of Book 3, the individual lament of Psalm 86 complements and overlaps thematically with the communal lament of Psalm 85, both of which address matters of sin (עטאתם מון עמך and, 85,3), the hope for restoration (85,8), and worship (ליראיו, 85,10). 85, As As an individual lament, then, Psalm 86 certainly fits into its immediate context of Psalms 73-89.

\footnotetext{
6 Casper J. Labuschagne, „Significant Sub-Groups in the Book of Psalms: A New Approach to the Compositional Structure of the Psalter, « in The Composition of the Book of Psalms, ed. E. Zenger (Leuven: Peeters, 2010): 623-634, here 624 with n. 2 and $629 \mathrm{f}$.

7 See the essays about »Perspectives on Editing in the Hebrew Bible and Ancient Judaism « in HeBAI 3.3 (2014): 293-354.

8 Frank-Lothar Hossfeld and Erich Zenger, Psalmen 51-100 (Herder: Freiburg, 2000), 32; 539. 9 Marvin E. Tate, Psalms 51-100, WBC 20 (Dallas: Word Books, 1990), 380. In terms of verbal usage as well as themes - sin, God as teacher, etc. - Psalm 25 and Psalm 86 share a good deal in common. But this paper focuses on intertextual links to the somewhat more dateable material in the Torah and Prophets.
} 
Identifying Psalm 86 as an individual lament is common. ${ }^{10}$ With some divergence in form (e.g., a second complaint in v. 14), it is a fairly standard example of the elastic lament type. It has the elements of address (v. 1), complaint (vv. 7.14), petition (v. 11), confession of trust (v. 2), and a vow of praise (v. 12). ${ }^{11}$ The psalm is divisible into three sections: vv. $1-7$; vv. 8-13; and vv. $14-17 .^{12}$ The first section focuses on the psalmist, who describes himself from the outset as "poor « and »needy«, but also as »loyal«, »trusting«, and cognizant of how his נפש depends on Yhwh to preserve and gladden it. He requests "mercy« (חנני, v. 3; and תחנון, v. 6) and predicates of Yhwh a readiness to »forgive« (סָלָ ${ }^{13}$ v. 5). By contrast, the second section focuses on Adonai, whom the psalmist initially praises as incomparable »among the gods" (אין־כמוך באלהים, v. 8) - a statement that may be intended ironically insofar as the speaker proceeds to state that Adonai alone occupies the genus of אתה אלהים לבדך, אלהים, v. 10; here, אלהים is not a name ${ }^{14}$ ). Consistent with this reasoning, Adonai is the maker (עשה לתח (עלחד) not just of Israel but of the world's nations, who, according to v. 9, will "worship« (חוה) and "glorify« (כבד) him. Notably, only after alluding to the nations' worship of Adonai does the psalmist transition to the topic of his own activity before Yhwh in vv. 11-13, the pivotal verses and petition (v. 11) addressed below that explain why the psalmist needs mercy and forgiveness. Finally, the third section re-introduces the element of complaint (v. 14) and the vulnerability of the psalmist's נפש. The speaker then lists the characteristics of Yhwh, asking again for »mercy« and »strength «. The concluding words announce retrospectively that Yhwh has indeed »helped « (pf. עזר) and »comforted« (pf. נחם) the lamenter (see also v. 13, והצלת נפשי).

The anthropology of the psalm, particularly its conceptions of sin and moral agency, becomes even clearer if one considers the intertextuality of Psalm 86.

10 Hermann Gunkel, Die Psalmen: übersetzt und erklärt (Göttingen: Vandenhoeck \& Ruprecht, 41926), 376; Claus Westermann, Lob und Klage in den Psalmen (Göttingen: Vandenhoeck \& Ruprecht, ${ }^{61983), ~ 142-144, ~ h e r e ~ 143 ; ~ K l a u s ~ S e y b o l d, ~ D i e ~ P s a l m e n: ~ E i n e ~ E i n f u ̈ h r u n g ~(S t u t t g a r t: ~ K o h l-~}$ hammer, 1986), 99; Jan Christian Gertz, ed., Grundinformation Altes Testament: Eine Einführung in Literatur, Religion und Geschichte des Alten Testaments (Göttingen: Vandenhoeck \& Ruprecht, $\left.{ }^{4} 2010\right), 423 \mathrm{f}$.

11 On the lament »type« of Psalm 13, see Bernd Janowski, Konfliktgespräche mit Gott: Eine Anthropologie der Psalmen (Neukirchen-Vluyn: Neukirchener Verlag, ${ }^{32009), ~ 39-46, ~ w h o ~ o n ~ p . ~} 42$ notes the flexibility of the lament components; and Gertz, ed., Grundinformation Altes Testament, $423 \mathrm{f}$. 12 On these divisions, see Jürgen Vorndran, »Alle Völker werden kommen«: Studien zu Psalm 86, BBB 133 (Berlin: Philo, 2002), 89f.; and Hossfeld and Zenger, Psalmen 51-100, $537 \mathrm{f}$.

13 The predications about Yhwh in v. 5 (אתה ... טוב וסלח ורב־חסד) anticipate v. 15, where the psalm quotes Ex 34,6.

14 אלהים appears in Ps 86,2.8.10.12.14. Only in v. 14 could the word pass for a divine name. 


\subsection{Intertextuality and some implications for dating Psalm 86}

In Psalm 86, a couple of verses (vv. 11.15) indicate the writer's access to the post-P Sinai material of Exodus 32-34. ${ }^{15}$ The clearest example is 86,15, which apparently quotes the list of divine traits from Ex 34,6 word for word. ${ }^{16}$ The similar lists elsewhere have fluctuating arrangements (cf. Num 14,18; Joel 2,13; Jon 4,2; Ps 103,8; 145,8; Neh 9,17), so the exact correspondence between Ps 86,15 and Ex 34,6 indicates that one text may in fact cite the other:

Table 1:

\begin{tabular}{|c|c|c|}
\hline Ex 34,6 & אל רחום וחנון ארך אפים ורב־חסד ואמת & $\begin{array}{l}{[\mathrm{DN}] \text {... a God compassionate and }} \\
\text { gracious, patient and great in steadfast } \\
\text { love and truth. }\end{array}$ \\
\hline Ps 86,15 & אל רחום וחנון ארך אפים ורב־חסד ואמת & $\begin{array}{l}{[\mathrm{DN}] \text {... a God compassionate and }} \\
\text { gracious, patient and great in steadfast } \\
\text { love and truth. }\end{array}$ \\
\hline
\end{tabular}

Calling to mind the context of these statements is instructive. Exodus 34,6 appears after Israel has worshipped the golden calf, after Moses has broken the tablets of the law, and during Moses' second experience on Mount Sinai while in the cloud (v. 5). Based on his having found חן in Yhwh's sight, Moses requests forgiveness for »our iniquity and our sin« (לעוננו ולחטאתנו). The focus here is covenant renewal from the "great $\sin$ (חטאה גדולה, Ex 32,30). Departing from the national setting of Exodus 32-34, the speaker in Ps 86,15 places Ex 34,6 into the context of an individual lament and speaks not of the nation's need for mercy but rather his own, individual need for it: »But you, O Adonai, are a God compassionate and gracious, patient and great in steadfast love and truth. Turn to me and be gracious (חנני) to me ...«(86,15-16). In addition to Ex 34,6, Hossfeld and Zenger detect a "play« « ${ }^{17}$

15 On the literary-historical placement of Exodus 32-34, see Konrad Schmid, Literaturgeschichte des Alten Testaments: Eine Einführung (Darmstadt: Wissenschaftliche Buchgesellschaft, 2008), 126-128, here 127.

16 Hossfeld and Zenger, Psalmen 51-100, 545 f. On the link between Ps 86,11 and Ex 33,12-14, see ibid., 543. Hermann Spieckermann argues that the seven complete lists of divine traits appear only in exilic and post-exilic texts, agreeing as well that Psalm 86 cites Exodus 34. See idem, "'Barmherzig und gnädig ist der Herrı, « in Gottes Liebe zu Israel: Studien zur Theologie des Alten Testaments, FAT 33 (Tübingen: Mohr Siebeck, 2001): here 4; 13. These lists of divine traits were at home in contexts concerned with the forgiveness of $\sin$.

17 Hossfeld and Zenger, Psalmen 51-100, 542; see also Vorndran, "Alle Völker werden kommen«, $208 \mathrm{f}$. 
on Ex 33,12-14 in the first colon of 86,11, which, due to differing verbs but similar syntax, seems a bit less clear but still quite plausible (note Hif. imv. ידע > Hif. imv. ירה; Qal impf. ידע > Piel impf. הלך).

Table 2:

\begin{tabular}{|c|c|c|}
\hline Ex 33,12-14 & בעיניך וראה כי עמך הגדכך ואדעך למען אמצא־חן & $\begin{array}{l}\text { Let me know your way, that I may know } \\
\text { you, that I may find favor in your sight. } \\
\text { See too that this nation is your people. }\end{array}$ \\
\hline Ps 86,11 & הורני יהוה דרכך אהלך באמתך... & $\begin{array}{l}\text { Teach me your way, O Yhwh, that I may } \\
\text { walk in your truth. }\end{array}$ \\
\hline
\end{tabular}

Through these intertextual links to Exodus 32-34, we see the nation as a faulty moral agent becoming the individual psalmist as a faulty moral agent, who nonetheless describes himself as חסיד (86,2). This self-description as important, since it suggests that the psalmist did not entertain a stark division between the pious and the impious, but, instead, classified both as morally faulty. In this psalm, not only the connection to Exodus 32-34 and the so-called Gnadenformel, but also other links to the Prophets show that Psalm 86 is part of an exilic and post-exilic discourse on the nature of $\sin$ as a problem that is inherent within human beings as such (cf. Psalm 51). ${ }^{18}$

Indeed, as reflected in this prayer’s imagery of the »heart (לבב, vv. 11-12) as a divided faculty, the anthropology of Psalm 86 is comparable to what one finds in a number of Second Temple Period texts that portray moral frailty and an inclination toward sin as internal to the human makeup. ${ }^{19}$ As is well known, the heart

18 Miryam T. Brand, Evil Within and Without: The Source of Sin and Its Nature as Portrayed in Second Temple Literature, JOAJSupp 9 (Göttingen: Vandenhoeck \& Ruprecht, 2013), notes that, in the Second Temple period, the genre of prayer was an important venue for communicating this idea of sin, though prayers expressed other conceptions of sin as well (here 37).

19 Brand, Evil Within and Without, here 19-25; 37. In her study of Second Temple conceptions of sin, Brand distinguishes between »sin« (»a transgression against God's will«) and »sinfulness» (»a state of the human being in which the human is perceived ... as stainted « with the desire to sin.«) (ibid., 26f.). The point is that the issue of sin and sinfulness was understood to involve rule breaking but not as being reducible to rule breaking. See also Loren T. Stuckenbruck, »The >Heart< in the Dead Sea Scrolls: Negotiating Between the Problem of Hypocrisy and Conflict within the Human Being, « in The Dead Sea Scrolls in Context: Integrating the Dead Sea Scrolls in the Study of Ancient Texts, Languages, and Cultures, Vol. 1, ed. Armin Lange et al. (Leiden: Brill, 2011): 437-453; Gary Anderson, Sin: A History (New Haven: Yale University Press, 2009), 15-39, who stresses the importance of attending to the metaphors that ancient Jewish scribes used for describing sin: chiefly, a »stain« from which one must be purified; a »burden« to be borne; and $\mathrm{a} »$ debt« that must be satisfied. 
was the governing center of thought, feeling, and action, which makes heart metaphors a good lens for tracking ideas of moral agency in the Hebrew Bible and related literature. The heart's condition determines the quality of moral agency. Of specific relevance to this paper, a number of texts envision the heart's frailty as a problem that can only be resolved through divine initiative. One example is Jeremiah 32, which Ps 86,11 picks up and adapts for the first person:

Table 3:

\begin{tabular}{|c|c|c|}
\hline Jer 32,39 & כל־הימים להם לב אחד ונודרך אחד ליראה אותי & $\begin{array}{l}\text { I will give them one heart and one way } \\
\text { to ירא me always. }\end{array}$ \\
\hline Ps 86,11 & ליראה שמרני יהוה דרכך אהלך באמתך יחד לבבי & $\begin{array}{l}\text { Teach me your way, } 0 \text { Yhwh, that I may } \\
\text { walk in you truth; unify my heart to ירא } \\
\text { your name. }\end{array}$ \\
\hline
\end{tabular}

In Jer 32,39, Israel's heart is too deeply flawed to generate proper action on its ירא me always« (נתים אחד ודרך אחד ליראה אותי כל־הימים; cf. לב אחד in Ez 11,19²). Yhwh's

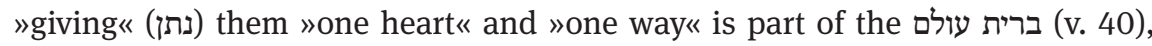
according to which the locus of יראת יהוה is not Israel but rather Yhwh himself: »I will place my (ואת־יראתי) יראה into their heart, so that they may not turn away from me.« Even though Jeremiah 32 regards Israel's current heart as salvagea-

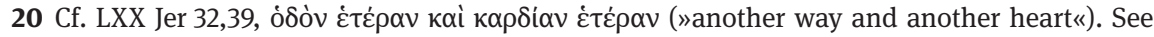

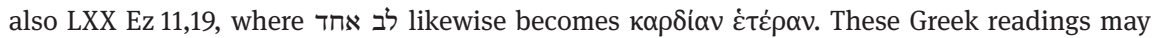
have originated through a misinterpretation of Heb. אחד (»one«) as אחר (»another«), the final consonants of which could easily be confused. Only two other Hebrew Bible texts contain the

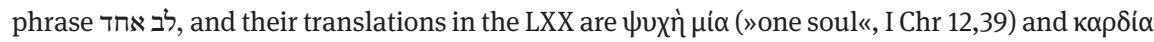
$\mu i \alpha$ (»one heart«, II Chr 30,12). Indeed, the reception of Jer 32,39 in Ps 86,11 seems to indicate

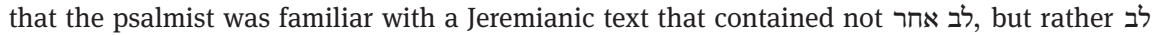
(יחד > אחד) אחד . On this text-critical issue in Jeremiah 32, see Konrad Schmid, Buchgestalten des Jeremiabuches: Untersuchungen zur Redaktions- und Rezeptionsgeschichte von Jer 30-33 im Kontext des Buches (Neukirchen-Vluyn: Neukirchener Verlag, 1996), 82 n. 143; and William L. Holladay, Jeremiah 2: A Commentary on the Book of the Prophet Jeremiah Chapters 26-52, Hermeneia (Minneapolis: Fortress Press, 1989), 220. See also the comments in Georg Fischer, Jeremia 26-52, HThKAT (Freiburg: Herder, 2005), 212.

21 In contrast to Jeremiah 32 and Psalm 86, Ez 11,19 and 36,26-27 use neither ירא nor in conjunction with the heart, suggesting that Psalm 86 interacts mainly with Jeremiah rather than with Ezekiel. But both Psalm 86 and Ez 11,19 seem to reflect an awareness of Jer 32,39. See Schmid, Buchgestalten des Jeremiabuches, 82-84; and Thomas Krüger, "Das menschliche Herz und die Weisung Gottes: Elemente einer Diskussion über Möglichkeiten und Grenzen der Tora-Rezeption im Alten Testament, « in Das menschliche Herz und die Weisung Gottes: Studien zur alttestamentlichen Anthropologie und Ethik, AThANT 96 (Zürich: TVZ, 2009): 127-132. 
ble (cf. Ez 36,26, לב חדש), the text identifies a precondition for the heart's proper functioning: Yhwh must implant his own יראה in the »one heart« (לב אחד) that he "gives« them.

But what does it mean for Yhwh to »give« people »one heart «? Jeremiah 32,39 would seem to qualify as a text that, in Marc Zvi Brettler's words, »[is] begging to be interpreted or reworked. «22 Psalm 86 retains the same distinctive cluster of terminology (דברד, לבירא 23) from Jer 32,39 with one particularly notable excep-

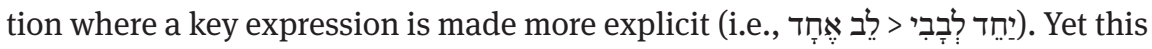
reworking of Jer 32,39 actually changes the heart metaphor: in Jeremiah 32, the image is a nation's heart that needs to be implanted with Yhwh's יראה (תורה =); but in Psalm 86, the image is an individual's heart that needs not implantation, but rather unification. That is, the psalmist speaks of his own לבב - the affective and cognitive center, the seat of passions and reason alike $e^{24}$ - as divided and therefore as incapable of independently generating action in tune with Yhwh's expectations. In order to function properly and generate יראה, what the psalmist and his divided לבב need is to receive instruction from Yhwh. The speaker in 86,11 communicates that, without this instruction, he is unable to conduct himself adequately and his לבב lacks an interior unity which it implicitly ought to have but does not have, suggesting that it is in some sense disordered. ${ }^{25}$

22 Marc Zvi Brettler, »Psalm 136 as an Interpretive Text, «HeBAI 2 (2013): 373-395, here 394.

23 Indeed, in a single verse, one finds this word cluster only in Deut 10,12; Jer 32,39; and Ps 86,11. The uneven parallelism in Ps 86,11 between the yiqțō אהלך and the infinitive construct ליראה may well reflect the fact that the psalmist is working with Jer 32,39, where one finds the same form and syntactical function of the verb ירא.

24 For a historical discussion of emotions and passions as different psychological taxonomies between which we should distinguish, see Phillip Michael Lasater, "»The Emotions in Biblical Anthropology? A Genealogy and Case Study with ירא, "Harvard Theological Review (forthcoming). On the import of the heart, see Carol A. Newsom, »Models of the Moral Self: Hebrew Bible and Second Temple Judaism, «JBL 131 (2012): 5-25, here 10; Jan Dietrich, »Individualität im Alten Testament, Alten Ägypten und Alten Orient, « in Menschenbilder und Körperkonzepte im Alten Israel, in Ägypten und im Alten Orient, ed. A. Berlejung et al., ORA 9 (Tübingen: Mohr Siebeck, 2012): 77-96, here 82-87; Thomas Staubli, »Alttestamentliche Konstellation der Rechtfertigung des Menschen vor Gott, « in Biblische Anthropologie: Neue Einsichten aus dem Alten Testament, ed. Christian Frevel (Freiburg: Herder, 2010): 113f.; and Thomas Krüger, »Das >Herz` in der alttestamentlichen Anthropologie, " in Anthropologische Aufbrüche: Alttestamentliche und interdisziplinäre Zugänge zur historischen Anthropologie, ed. Andreas Wagner, FRLANT 232 (Göttingen: Vandenhoeck \& Ruprecht, 2009): 103-118, here 104.

25 For a helpful discussion of various »dualisms « in Ben Sira, 1 Enoch, and especially Qumran texts, see Loren T. Stuckenbruck, "The Interiorization of Dualism within the Human Being in Second Temple Judaism: The Treatise of the Two Spirits (1QS III,13-IV,26) in its Tradition-Historical Context, « in Light Against Darkness: Dualism in Ancient Mediterranean Religion and the Con- 


\section{Psalm 86, impaired moral agency, and law as the solution}

The reception of Jeremiah 32 in Psalm 86 moves beyond Jer 32,38-41 by individ-

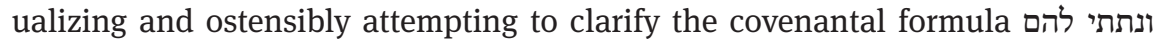

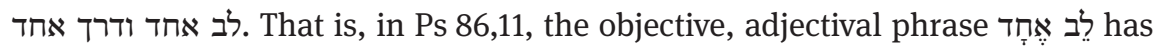

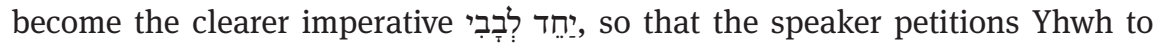
enable proper moral agency by granting unity to a human heart impaired by division. Unless this problem of internal division is resolved, the לבב seems incapable of generating יראה, a passion that elsewhere arises matter-of-factly from the לבב (e.g., I Sam 28,5; Ps 27,3; 112,7-8). To call for divine transformation of certain bodily organs was one way that Second Temple period texts spoke about sin as a problem of human nature from which people needed to be freed (e.g., 11QPs XXIV.11-13a; 4QBarkhi Nafshi 1.i.2-4; see also Jer 31,33-34; Ez 36,26-27; Ps 51,12). עון in order to make conceptual points about sin, though it is revealing that Ps 86,5 would stress that Adonai is "good and forgiving" (טוב וסלח; plus, note עון and חטאת in 85,3). What often expressed such conceptions of sin were metaphors of God's transforming bodily organs, especially the heart. This metaphorical tie to bodily organs exemplifies how some scribes in the Second Temple period were already conceptualizing sin not just as moral agents' misdeeds, but more fundamentally as the condition that cultivates misdeeds and requires treatment. This talk of transforming organs commonly appears alongside an emphasis on divine instruction or law, which we also see in Psalm 86 (i.e., ירה [III] in Ps 86,11; plus, the links to Exodus 32-34; Jeremiah 30-33).

To see how divine instruction relates to the divided heart in Psalm 86, one should consider the parallelism in the bicola of Ps 86,11-12:

Table 4:

\begin{tabular}{|c|c|c|c|}
\hline v. 11 & A & 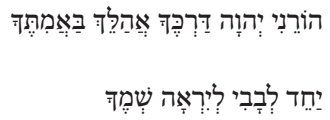 & $\begin{array}{l}\text { Teach me your way, O Yhwh, that I may } \\
\text { walk in your truth; } \\
\text { unify my לבב that it may ירא your name; }\end{array}$ \\
\hline \multirow[t]{2}{*}{ v. 12} & A & 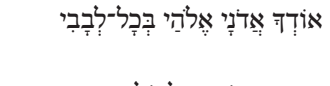 & $\begin{array}{l}\text { I will praise }{ }^{26} \text { you, } 0 \text { Adonai my God, } \\
\text { with my whole לבב; }\end{array}$ \\
\hline & B & 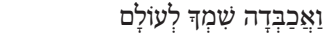 & I will glorify your name always. \\
\hline
\end{tabular}

temporary World, ed. Armin Lange et al., JAJSup 2 (Göttingen: Vandenhoeck \& Ruprecht, 2011): 145-168.

26 See $n .3$ above. 
As James Kugel and Patrick D. Miller have shown, Hebrew parallelism involves bicola that »second « or build upon one another, with the individual cola functioning to help textual meaning and logic unfold (e.g., via echoing, contrasting, specifying, sequencing, subordinating, etc.). ${ }^{27}$ Theoretically, then, the B clause in a parallel unit is where the conceptual emphasis belongs. ${ }^{28}$ With volitional forms beginning every bicolon except one (12 A) in Ps 86,11-12, verse 11 focuses on what Yhwh must do in order to facilitate the psalmist's activity in verse 12, so that

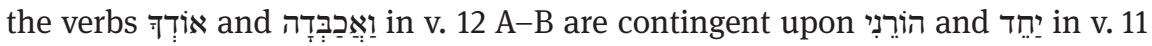
A-B. In other words, the psalmist's "praising " and "glorifying « can only occur if Yhwh has already »instructed» the psalmist and »unified« his לבב. The contrast between the divided heart (v. 11) and the »whole heart« (v. 12) at the center of 86,11-12 seems to confirm this logical relationship between the sets of bicola, with vv. 12-13 marking a shift in the psalmist's experience by expressing what is the case now that his heart has been »unified « and his soul »delivered».

Likewise, the same kind of contingent relationship between the verbs in vv. 11-12 emerges within v. 11 itself, where the connection between divine instruction and the divided לבב helps us see the conception of moral agency at work in Psalm 86. The verbal sequences in 86,11 alternate between divine and human actions: Yhwh is the subject of two imperatives in independent clauses, and the psalmist is the subject of a yiqtōl and an infinitive construct with ?-prefix

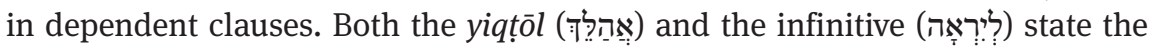

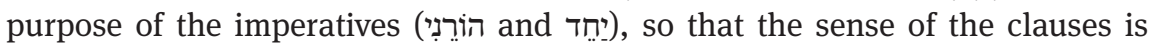
»Teach me ... that I may walk ...« and »Unify my לבב, that it may ירבי" (on the form

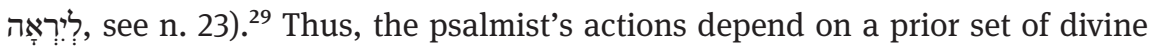
actions to alter an impaired human agency, giving the moral agent the ability to generate proper conduct (i.e., יראת יהוה).

In Ps 86,11, the two divine actions of »teaching " and "unifying " deserve attention. In colon A, when the speaker petitions Yhwh to »teach me your way", the combination of Hif. ירה mith דרך may invoke a version of the Torah, ${ }^{31}$ which is

27 See James Kugel, The Idea of Biblical Poetry: Parallelism and Its History (Baltimore: The Johns Hopkins University Press, 1998), here 2-15; and Patrick D. Miller, Interpreting the Psalms (Philadelphia: Fortress Press, 1986), 30-47.

28 Kugel, Idea of Biblical Poetry, 51, notes that »the real point « of the pauses between parallel clauses is »the subjoined, hence emphatic, character of B. "See also Miller, Interpreting the Psalms, $33 \mathrm{f}$.

29 Dahood, Psalms II, 295.

30 See the brief comments in Manfred Oeming, Das Buch der Psalmen (Stuttgart: Katholisches Bibelwerk, 2010), 249.

31 Hossfeld and Zenger, Psalmen 51-100, 543-544; Vorndran, "Alle Völker werden kommen«, $208 \mathrm{f}$. 
possible if the post-exilic composer knew both Exodus 32-34 and Jeremiah 30-33. Even though the word תורה is not in Psalm 86, the psalmist's interaction with Exodus 32-34 and Jeremiah 30-33, as well as the usage of Hif. ירד with Yhwh's in other texts, ${ }^{32}$ makes it quite plausible to read Ps 86,11 not simply in terms of an unbranded teaching, but of the Torah. In any event, whether some version of the Torah or a more generic instruction is in view (cf. תורה in Psalm 11933), the idea is that receiving divine teaching directly from Yhwh is a prerequisite for the psalmist's adherence to Yhwh's »way" and »truth« (אמת). Adhering to Yhwh is not a אוּהַלֵּד on הiֹרֵני illustrates. ${ }^{34}$ What is involved in or at least correlates with the speaker's receiving this teaching? That is likely the sort of question that colon B answers by mentioning for the first time the state of the speaker's underperforming heart.

Building upon colon A's petition for divine instruction or law, the psalmist in colon B petitions Yhwh to »unify my לבב, that it may ירא your name«, so that, like Jeremiah 32, the heart's capability hinges on the antecedent divine action of granting »one[ness]《 to (לב אחד) or »unifying«this human faculty (יחד לבבי). But as stated above, these two heart metaphors are not identical. Whereas in Jeremiah Yhwh »grants« (נתן) Israel »one heart« and implants יראה within it, in the psalm Yhwh is petitioned to perform unifying action (Piel יחד ירזי) on an individual's heart that only subsequently can foster יראה, portraying individual, interiorized division as an ethical and theological problem..$^{35}$ To be sure, Psalm 86 says nothing about oppositional cosmic forces contending "in the heart of man« (e.g., 1QS 4,23; יריבו רוחי אמת ועול בלבב גבר. The dilemma in Psalm 86 is not about demonic לבב forces that manifest themselves through inner conflict, but rather about the as a flawed organ that, even for the חסידים (86,2), yields disordered thoughts and desires - thoughts and desires that are gauged according to an exterior, norma-

32 For Hif. ירה + Yhwh's דרך in texts with the word תורה, see Isa 2,3; Mi 4,2; Ps 119,33-34. And for this combination with עדות and, see Ps 25,8-12.

33 See Jon D. Levenson, »The Sources of Torah: Psalm 119 and the Modes of Revelation in Second Temple Judaism, « in Ancient Israelite Religion: Essays in Honor of Frank Moore Cross, ed. Patrick D. Miller et al. (Minneapolis: Fortress Press, 1987): 559-574, here 566.

34 Cf., e.g., the receipt of knowledge in 1QS 11,15-16: "Blessed are you, O my God, who opens the heart of your servant to knowledge. Establish all his deeds in righteousness« (לרוך אתה אלי הפותח) (לדעה לב עבדכה הכן בצדק כול מעשיו).

35 On scribes' moral suspicion toward human interiority, see Dietrich, »Individualität im Alten Testament«: 84 . However, it seems doubtful that their reflections on interiority were only concerned with the implications for social and legal relations as opposed to, say, articulating theological anthropology (»Die reflektierte Innenschau wird hier allein aufgrund ihrer Bedeutung für die Sozial- bzw. Rechtswelt bewertet«).

36 »The spirits of truth and iniquity contend in the heart of man« (my translation). 
tive standard. Hence, in Ps 86,11, the idea is that the לבב is divided, but that it ought not be divided. This text provides a glimpse into a Second Temple period scribe's grappling with moral struggle, which per se would eventually be seen as symptomatic of the problem of evil. ${ }^{37}$ Indeed, in a number of ancient Jewish (and Christian ${ }^{38}$ ) writings, this problem surfaces anthropologically as the inborn desire to or inclination toward sin (e.g., Gen 6,5; 8,21; Ps 51,3-5; Eccl 9,3; CD 2,15-17; 1QS 4,23; 4Q436 frag. 1.i.10; cf. Rom 7,14-20; see later Confessions VIII 8,19-9,21; City of God XIX 4). The relevance of Psalm 86 to this Second Temple period discourse is nowadays overlooked, ${ }^{39}$ but, like some Rabbinic texts (e.g., b. Qidd. 30.b; Sifre Deut. 45), ${ }^{40}$ it presents divine law or instruction almost medicinally as that which heals the heart's disorderly fragmentation.

In view of these heart metaphors from Second Temple literature, Rabbinic texts that later speak of »the evil inclination« (יצר הרע) locate it, naturally enough,

37 See Brand, Evil Within and Without, 19-27; and also Geert Hendrik Cohen Stuart, The struggle in man between good and evil: An inquiry into the origin of the Rabbinic concept of Yeșer Harar (Kampen: J. H. Kok, 1984), 223-230. The notion that moral struggle is itself symptomatic of the problem of evil played a major role among classical Christian thinkers, including, yet hardly limited to, Augustine and Aquinas. But Jennifer Herdt notes that a major shift occurred among some late medieval scholastics - i.e. Duns Scotus and esp. William of Ockham and his Franciscan followers - who denied that intellect is prior to will and defined »freedom « as »the will's indifference (Putting on Virtue: The Legacy of the Splendid Vices [Chicago: The University of Chicago Press, 2008], here 92 and 93). The upshot was that, in some circles, »the life of moral struggle began to emerge as a heroic ideal« (ibid., 92). In other words, the divided »mind« or "self" that had formerly been seen as pointing toward the problem of evil came to be affirmed as something honorable.

38 On sin as a universal anthropological problem in Paul, see N. T. Wright, Paul and the Faithfulness of God, COQG (London: SPCK, 2013), 3; 754 f.; Michael Wolter, Paulus: Ein Grundriss seiner Theologie (Neukirchen-Vluyn: Neukirchener Verlagsgesellschaft, 2011), 376-383. See also William E. Mann, »Augustine on evil and original sin, « in The Cambridge Companion to Augustine, ed. Eleonore Stump and Norman Kretzmann (Cambridge: Cambridge University Press, repr. 2005 [orig. 2001]): 40-48, here 45-48.

39 Prior to the modern period and even early in the modern period, this overlooking of Psalm 86 was not the case (see below for Rabbinic texts). John Calvin picked up on this point in Ps 86,11 and discussed the text in Institutes 2.3.9 under the heading »The prayers in Scripture especially show how the beginning, continuation, and end of our blessedness come from God alone." The focus in Book 2 of Calvin's Institutes is how people come to have knowledge of God as redeemer, and how the corrupted human will is unable on its own to acquire such knowledge. On the psalmist's request to »Unite my heart to fear your name«, Calvin states that »By these words he means that even well-disposed persons have been subject to so many distractions that they readily vanish or fall away unless they are strengthened to persevere ... Therefore the Lord in this way both begins and completes the good work in us. It is the Lord's doing that the will conceives the love of what is right, is zealously inclined toward it, is aroused and moved to pursue it." 40 Brand, Evil Within and Without, 38. 
יצר makes sin inevitable until it is mastered or removed and the heart is unified (see earlier, e.g., 4Q436 frag. 1.i.10). ${ }^{42}$ The understanding among some Rabbis was that God's unity has normative implications for assessing human moral psychology, with internal unity being judged superior to division. ${ }^{43}$ For this reason, the יצר ought to be removed: "Just as He is singular (יחידי) in the world, so let your service be singular (מיוחדת) before him « (Sifra Shemini 1; note the double use of יחד derivatives). ${ }^{44}$ Commenting on David's moral struggle with his antinomian יצר, the writer of Exodus Rabbah cites Ps 119,80 and Ps 86,11 to illustrate David's dependence on divine instruction for the unity of his heart:

Its [sic] is written: »Let my heart be undivided in thy statutes in order that I may not be put to shame (Ps. 119,80)«. David said: »Lord of the Universe! When I occupy myself with your statutes, let not the Evil Yeșer have power to influence me ..., as it says: ‘Teach me, O Lord, Thy way, that I may walk in Thy truth (Ps. 86,11)<; namely, that the Evil Yeșer do [sic] not lead me astray ... and make me shamefaced before the righteous. Moreover, if he misleads me I will neglect the study of the Torah, and when I proclaim my learning before Thee and those lesser than I am, they will say to me: ıIt is not so<; with the result that I will be put to shame. I beseech Thee, therefore, to make my heart whole that I may occupy myself with the Torah in integrity. « $^{45}$

With definite reference to Ps 86,11, Exodus Rabbah regards the heart's division as a problem of moral agency wrought by the presence of יצר הרע, whose influence the speaker asks God to restrain through divine instruction that leads to the heart's "wholeness« or unity. Even if one brackets the specific notion of יצר הרע ${ }^{46}$ the above discussion of the bicola in Ps 86,11-12 seems to support the

41 Ishay Rosen-Zvi, Demonic Desires: Yetzer Hara and the Problem of Evil in Late Antiquity (Philadelphia: University of Pennsylvania Press, 2011), 2 and n. 3.

42 The Rabbis generally assumed one יצרים יצר (i.e., a "good" vs. an »evil« יצר). Thus, were mostly interchangeable terms, even though a few texts do speak of a "good" יצר הרע יצר (יצר יצר (Brand, Evil Within and Without, 21 n. 7 and n. 11; Rosen-Zvi, Demonic Desires, 12f.). Rosen-Zvi has argued that יצר הרע was associated with demonic forces that became internalized. Although his link between the יצר and demons has merit, it is somewhat overstated (see Brand, Evil Within and Without, 46f.).

43 Rosen-Zvi, Demonic Desires, 158 n. 33.

44 Translation from ibid., 41 and 158 n. 33.

45 Translation from Stuart, The struggle in man, 56.

46 Exodus Rabbah connects the experience of disorderly desires and thoughts to the יצר הרע. While it is of course true that »the fully developed rabbinic concept of the יצר הרע is not to be found in the literature of the Second Temple« (Newsom, "Models of the Moral Self«: here 16 [my emphasis]), one should not overstate the conceptual distance between Rabbinic texts and Second Temple period texts. 
Rabbinic reading of this text in terms of impaired moral agency. Much like the pattern in Exodus Rabbah, the psalmist's reception of Yhwh's teaching is what unifies his divided heart and enables it to ירא, so that, in tune with this conception of limited agency, an endowed knowledge is the beginning of יראת יהוה rather than vice versa (cf. Prov 1,7; 9,10). Furthermore, the psalmist in 86,13 understands this endowed, "unifying « teaching or torah as inseparable from an expression of divine חסד, "steadfast love«, that rehabilitates moral agency. Between Ps 86,11 and 86,13, Yhwh's action upon the »divided» heart paves the way for human agency with the "whole heart«, and Yhwh accomplishes the task through a torah that is virtually indistinguishable from a display of his חסד.

Like other Second Temple period prayers with comparable anthropologies, the portrayal of moral agency in Psalm 86 raises what is prima facie a paradox. We noted above how the divided לבב would produce disordered or inadequate thoughts and desires when operating on its own, which explains the need for Yhwh to "unify« it, so that it can incline properly toward Yhwh and serve as the locus of יראת יהוה psalmist's awareness not only that his לבב יראוn is divided, but also that it ought not be divided, suggests that the composer takes for granted some degree of inclination toward Yhwh and Yhwh's instruction (recall the self-description in 86,2, חסיד and (הבוטח אלך). Carol A. Newsom has argued that moral agency in the Hebrew Bible revolves around a flexible yet "fundamental grammar of the moral self», which consists of desire, knowledge, and submission to external authority. ${ }^{48}$ Borrowing Newsom's taxonomy, the profile of moral agency in Psalm 86 would be that cognition and desire, being present yet inept and divided, are out of sync with the ability to submit independently to external authority - an inability due in no small part to a lack of knowledge. Accordingly, the issue in Psalm 86 is not a complete absence of good desires and thoughts, but rather their inevitably deficient competency. In the logic of this psalm, without Yhwh's assistance in »unifying« what is divided, the incompetency of the לבב will continue unabated.

47 On the »heart« and the idea of »inclination«, see Brand, Evil Within and Without, 28f.; Stuart, The struggle in man, 223-225.

48 Newsom, »Models of the Moral Self«: 12. 


\section{Appendix: Usages of the verb יחד}

יחד (related etymologically to אחד, »one«) has nominal, adverbial, and verbal derivatives, virtually all of which express some notion of »togetherness « or »unity«. The nominal form יַחי (»community«) is common in the Dead Sea Scrolls as a self-description of the group at Qumran, and the adverb יחסד (»together, altogether, all at once «) is relatively frequent in the Hebrew Bible (HALOT 2:405; note

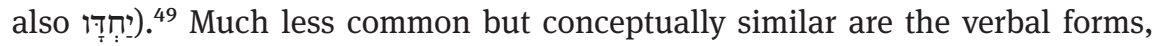
which appear three times in the Hebrew Bible and once in Ben Sira. These four cases are as follows:

Table 5: Verbal forms of יחד

\begin{tabular}{|c|c|c|}
\hline Gen 49,5-6 & 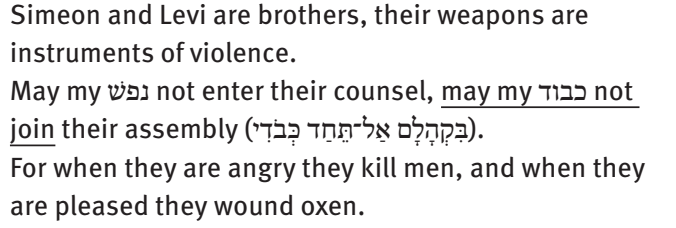 & Qal imperfect \\
\hline Isa $14,18.20$ & 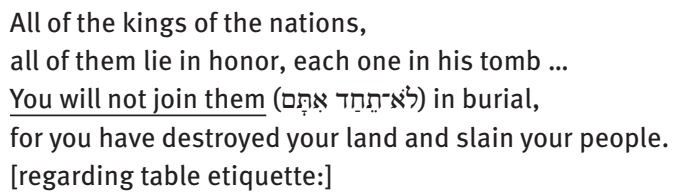 & Qal imperfect \\
\hline & $\begin{array}{l}\text { Do not extend your hand toward the place he is } \\
\text { looking, } \\
\text { nor join }\left(T \mathrm{~T}^{50}\right) \text { it in the dish with him. }\end{array}$ & Qal or Piel imperfect \\
\hline Ps 86,11 & 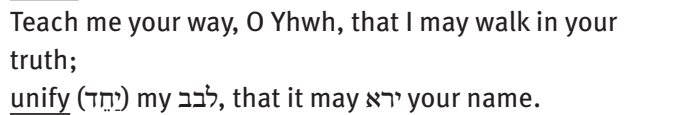 & Piel imperative \\
\hline
\end{tabular}

Semantically, the idea of (dis)unity is clearly at play in the use of the verb. The first three texts in Table 5 describe ways in which someone »joins« (or rather, does not »join «) others in a particular activity or state. Each scenario is publicly or externally observable - i.e., becoming part of an assembly; burial; and dining. Psalm 86 is obviously an exception in this sense: Although the verb's semantics still concern the idea of unity, the topic is not a public activity with other people.

49 See Bruce K. Waltke and Michael O’Connor, An Introduction to Biblical Hebrew Syntax (Winona Lake: Eisenbrauns, ${ }^{2} 1990$ ), 274.

50 HALOT 2:405 reads this form as a Piel, but Accordance classifies it as a Qal. 
Instead, the topic is the moral condition of the psalmist's heart. His heart is the object of the Piel verb יחי, whose grammatical subject is Yhwh, the addressee. Nowhere else does יחד appear unambiguously in the Piel (Sir 31,14?), but, contextually, this use of it in Ps 86,11 is hardly puzzling. The volitive clause יחד לבבי in Ps 86,11 involves a unique usage of the verb יחד, but this uniqueness creates no problem of understanding. Not only the intertextual link between Ps 86,11 and Jer 32,39, but arguably also the Rabbinic reception of Ps 86,11, further supports

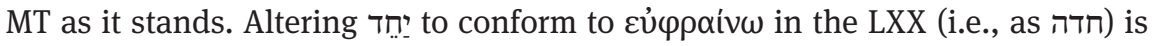
thus unnecessary and obscures the psalmist's reworking of the covenant formula from Jer 32,39. Given the factitive nuances of the Piel, the most reasonable translation of the imperative יחת in Psalm 86 is »unify.«

Abstract: Psalm 86 is a text that displays intertextual engagement with Exodus 32-34 and Jeremiah 30-33, both of which are older than the psalm. In studies of Psalm 86, a neglected issue is its anthropology, particularly the notion of the »divided heart«, which, according to the psalmist, is an ethical and theological problem that can only be solved by receiving instruction from Yhwh - an instruction that can "unify« the divided heart. By paying attention to the psalmist's application and reworking of older texts, as well as to the Rabbinic reception of Psalm 86, one can see how this text is part of an exilic and post-exilic conversation about human sinfulness as a flaw in human nature that impairs moral agency.

Zusammenfassung: Psalm 86 enthält intertextuelle Verbindungen mit Exodus 32-34 und Jeremia 30-33. Diese Texte aus dem Pentateuch und den Propheten sind älter als Psalm 86. Ein bisher in der Forschung vernachlässigtes Thema in diesem Psalm ist die implizierte Anthropologie, die sich an der Rede über das "geteilte Herz « festmachen lässt. Dieses gilt in diesem Kontext als ethisches und theologisches Problem, das nur durch eine göttliche Weisung gelöst werden kann, weil diese Lehre das Herz »einigt«. Wenn man beachtet, wie einerseits der Psalmist ältere Texte übernimmt und überarbeitet und wie andererseits Psalm 86 in der rabbinischen Literatur rezipiert wird, zeigt sich, dass Psalm 86 an einem Gespräch in exilischer und nachexilischer Zeit teilnimmt, in welchem die Sünde als ein Makel der menschlichen Natur thematisiert wird, der die moralische Handlungsfähigkeit beeinträchtigt.

Résumé: L'intertextualité qu'on observe entre le Psaume 86, Exode 32-34 et Jérémie 30-33 suggère que le Psaume 86 date de l'époque exilique ou post-exilique. En ce qui concerne la supplication du v. 11 on n'a guère prêté attention au motif du »coeur divisé«. Selon le Psalmiste, il s'agit-là d'un problème éthique et 
théologique qui peut seulement être résolu grâce à l'instruction venant de Yhwh. C'est une instruction "unifiante« liée d'une manière intrinsèque à la divine חסד. La reprise d'autres textes dans ce Psaume ainsi que sa récéption rabbinique montrent que le Ps 86 fait partie d'une discussion exilique et post-exilique sur la condition pécheresse, une condition qui entrave le libre arbitre. 